\title{
Evaluation of seasonal antioxidant activity and total phenolic compounds in stems and leaves of some almond (Prunus amygdalus L.) varieties
}

Aysel Sivaci $^{1 *}$ and Sevcan Duman ${ }^{2}$

\begin{abstract}
Background: This study aimed to determine the seasonal changes of total antioxidant activity and phenolic compounds in samples taken from leaves (April, July, October) and stems (April, July, October, January) of some almond (Prunus amygdalus L.) varieties (Nonpareil, Ferragnes and Texas).

Results: It was indicated that antioxidant activity and phenolic compounds in leaves and stems of Nonpareil, Ferragnes and Texas showed seasonal differences. Antioxidant activity $I C_{50}$ of these varieties reached the highest value in April for leaves whereas in October for stems. The highest level of total phenolic compounds was in January for stems while in October for leaves.

Conclusions: These results showed that total antioxidant activity and phenolics in leaves and stems of almond varieties changed according to season and plant organ.
\end{abstract}

Keywords: Almond, Antioxidant activity, Phenolics, Prunus amygdalus, Seasonal changes

\section{Background}

Climate is a factor which affects agricultural production. Increase of temperature or variations in precipitation ratio affect physiological events in plants [1-3].

Almond belongs to Rosaceae family and is an important product due to high commercial value of its fruits. Its fruits are nutritious due to their protein, fat, mineral substance, fibre and vitamin E content [4-10].

Natural products derived from plants are used for health supplements [11]. Antioxidants are compounds which prevent or delay the oxidation of lipids or other molecules by inhibiting the initiation or propagation of oxidative chain reactions have positive effects on human health $[12,13]$. Phenolic substances are one of the most widely known substances with their antioxidant characteristics $[14,15]$. Phenolic substances are metabolites with different structure and functions, having an aromatic ring containing generally one or more hydroxyl group [16,17]. Antioxidant effects of phenolic compounds are explained by bonding free radicals, forming chelate with metals and inactivating

\footnotetext{
*Correspondence: asivaci@gmail.com

'Department of Biology, Art and Science Faculty, Adiyaman University, Adiyaman, Turkey

Full list of author information is available at the end of the article
}

some enzymes [18]. Various studies carried out on almond cultivars showed that almond fruit and sections have phenolic compounds and antioxidant activity [19-23].

Analysis of previous research on almonds focused on investigating the antioxidant activity and phenolic compounds mostly in fruits, and the changes in stem and leaves have not been studied on seasonal basis. This study will be significant for determining beneficial compounds in different organs of almond varieties, on seasonal basis, the possibility of making use of these organs and explaining the variations in this plant under different climatic conditions. Therefore, this study investigated seasonal total antioxidant activity and total phenolic compounds in leaves and stems of some almond varieties (Nonpareil, Ferragnes and Texas) which are distributed in Adiyaman province of Turkey.

\section{Results}

Total antioxidant activity

It was found that total antioxidant activity varied according to season, plant organs and varieties (Figures 1 and 2). Total antioxidant capacity in the leaves of almond varieties $\left(\mathrm{IC}_{50}\right)$ was low in April in Texas, Ferragnes and Nonpareil (high antioxidant activity) (Texas, $88.67 \quad \mu \mathrm{g} \mathrm{mL} \mathrm{m}^{-1}$; 


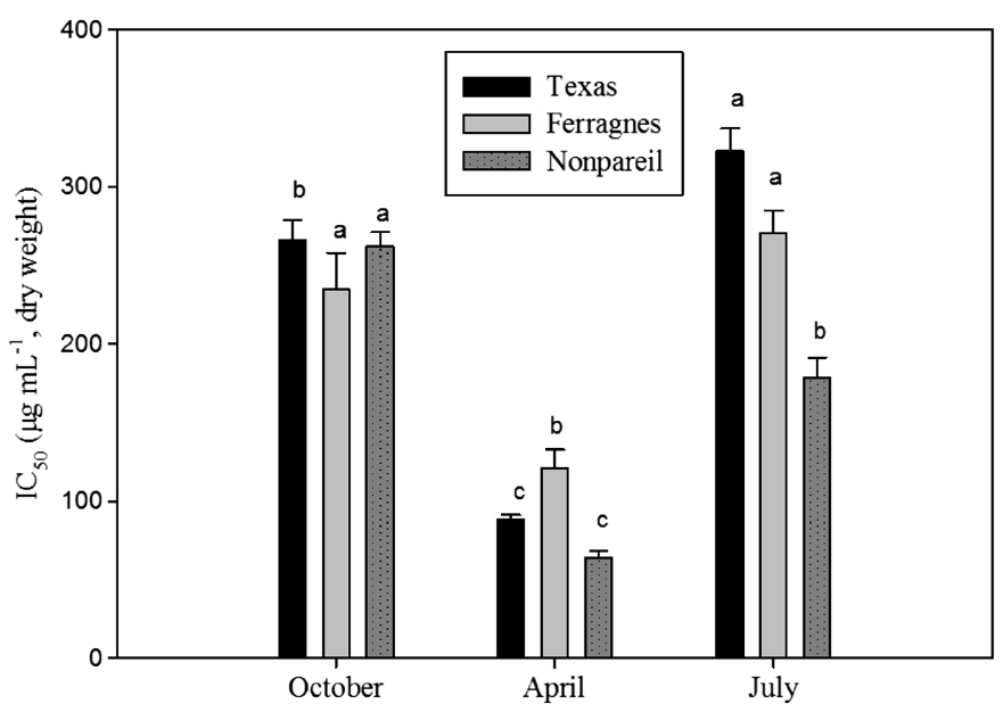

Figure 1 Seasonal total $I_{50}$ changes in leaves of Nonpareil, Texas and Ferragnes in DPPH. (Data followed by different letters are significantly different from each other $(p<0.05)$ according to Duncan's test).

Ferragnes, $121 \mu \mathrm{g} \mathrm{mL}^{-1}$; Nonpareil, $\left.64 \mu \mathrm{g} \mathrm{mL}^{-1}\right)(\mathrm{p}<0.05)$. The highest $\mathrm{IC}_{50}$ value (low antioxidant activity) was found in July for Texas, Ferragnes and in October for Nonpareil (Figure 1). It was determined that antioxidant capacity was the lowest for Nonpareil (high antioxidant activity) and high (low antioxidant activity) for Ferragnes in April (Figure 1) $(\mathrm{p}<0.05)$.

$\mathrm{IC}_{50}$ values in the stems of almond varieties were low in October (high antioxidant activity) (Texas, $79.16 \mu \mathrm{g} \mathrm{mL}^{-1}$; Ferragnes, $174.46 \mu \mathrm{g} \mathrm{mL}{ }^{-1}$; Nonpareil, $73.50 \mu \mathrm{g} \mathrm{mL}{ }^{-1}$ ); and high in April (low antioxidant activity) (Texas, $207.79 \mu \mathrm{g} \mathrm{mL}^{-1}$; Ferragnes, $200.67 \mu \mathrm{g} \mathrm{mL}{ }^{-1}$; Nonpareil,
$137.67 \mu \mathrm{g} \mathrm{m}^{-1}$ ) (Figure 2). The variation in antioxidant activity was significant in other varieties excluding Ferragnes $(\mathrm{p}<0.05) . \mathrm{IC}_{50}$ values of Ferragnes and Texas varieties were similar in July and January. On the other hand, it was found that $\mathrm{IC}_{50}$ values were at the lowest level in Nonpareil and Texas (high antioxidant activity) and high in Ferragnes (low antioxidant activity) in October (Figure 2).

\section{Total phenolic compounds}

Phenolic compounds in the leaves of Nonpareil, Texas and Ferragnes varieties were high in October (Figure 3) $(\mathrm{p}<0.05)$. In this month, values of phenolic compounds

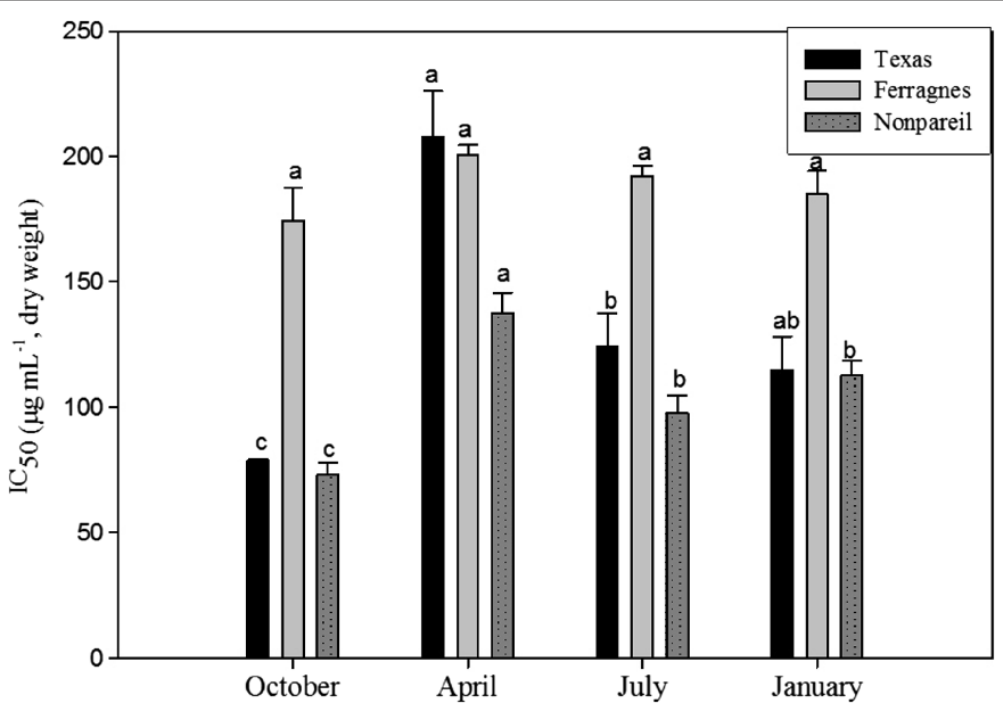

Figure 2 Seasonal total $I_{50}$ changes in stems of Nonpareil, Texas and Ferragnes in DPPH. (Data followed by different letters are significantly different from each other $(p<0.05)$ according to Duncan's test). 


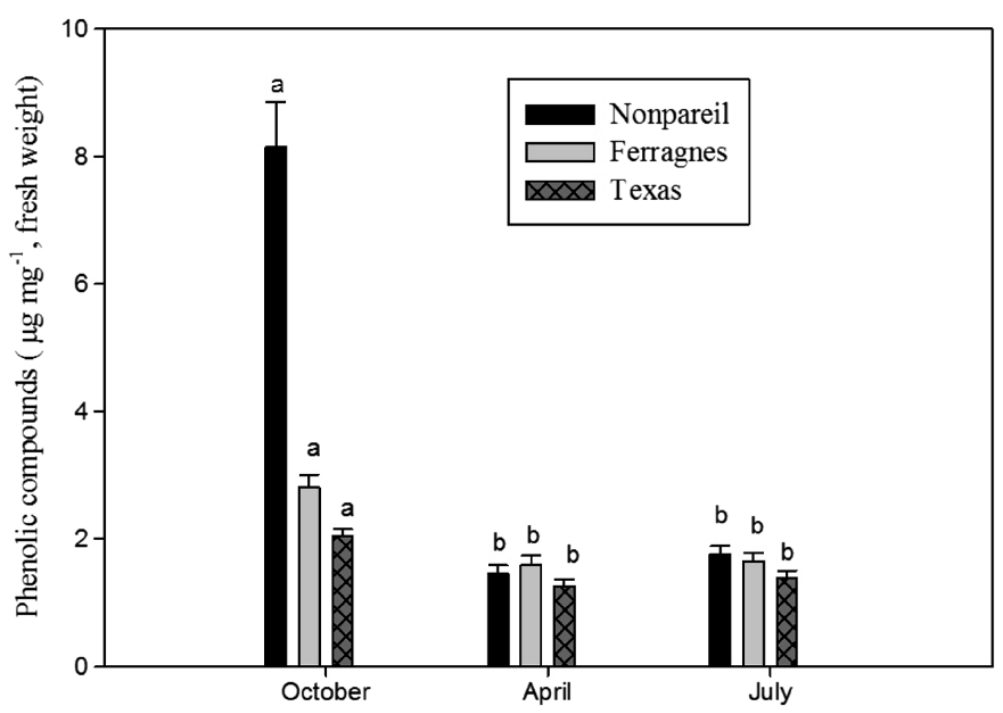

Figure 3 Seasonal total phenolic compounds in leaves of Nonpareil, Texas and Ferragnes. (Data followed by different letters are significantly different from each other $(p<0.05)$ according to Duncan's test).

of Texas, Ferragnes and Nonpareil were $2.03 \mu \mathrm{g} \mathrm{mg} \mathrm{g}^{-1}$, $2.82 \mu \mathrm{g} \mathrm{mg}^{-1}$ and $8.15 \mu \mathrm{g} \mathrm{mg}^{-1}$ respectively. In all varieties, phenolic compounds were low in April and July and the variations observing in April and July were not significant statistically (Figure 3$)(\mathrm{p}>0.05)$.

It was found that phenolic compounds in the stems of almond varieties also varied according to months. In all varieties, phenolic compounds were the highest in January (Teksas, $2.08 \mu \mathrm{g} \mathrm{mg}^{-1}$; Ferragnes, $1.85 \mu \mathrm{g} \mathrm{mg}^{-1}$; Nonpareil, $\left.2.90 \mu \mathrm{g} \mathrm{mg}^{-1}\right)$ (Figure 4) $(\mathrm{p}<0.05)$. The lowest phenolic compound contents were in October $\left(0.95 \mu \mathrm{g} \mathrm{mg}^{-1}\right)$ and
July $\left(1.08 \mu \mathrm{g} \mathrm{mg}^{-1}\right)$ for Ferragnes and; in April for Texas $\left(0.77 \mu \mathrm{g} \mathrm{mg}^{-1}\right)$. In Nonpareil, levels of phenolic compounds were higher than other two varieties in all months (Figure 4).

\section{Discussion}

Nunes et al. [24] carried out a study in red propolis and investigated the effect of season on antioxidant activity and total phenols. The researchers reported that there was a correlation between total antioxidant activity and season and that phenol content was high in hydra-

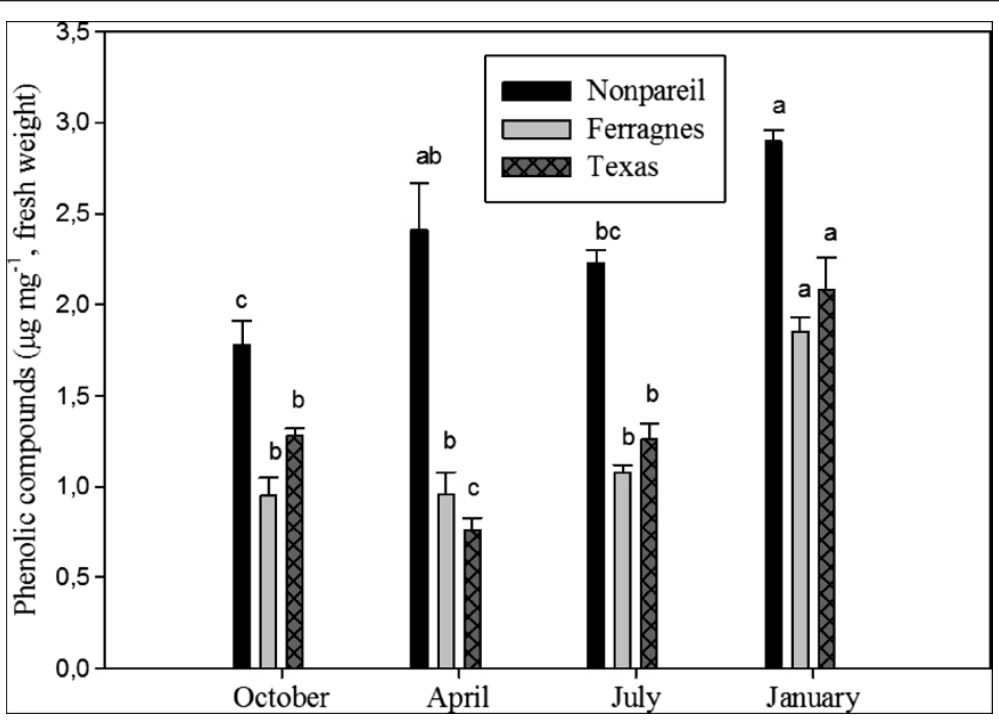

Figure 4 Seasonal total phenolic compounds in stems of Nonpareil, Texas and Ferragnes. (Data followed by different letters are significantly different from each other $(p<0.05)$ according to Duncan's test). 
alcoholic (90\%) concentration in October. Ignacio et al. [25] reported that photosynthetic pigment and antioxidant activity in Fagus sylvetica L. varied by sun and light conditions.

In another study, carried out on different cultivars of California almonds, it was determined that flavonoid content and antioxidant activity depended on the cultivar rather than season [20]. As indicated above, this study found that antioxidant activity showed seasonal variations in stem and leaves of almond varieties (Nonpareil, Texas and Ferragnes) (Figures 1 and 2). Esfahlan and Jamei [26] carried out a study in fruits of ten wild almond species and reported that there were variations in flavonoid, phenolic contents and antioxidant activities according to almond species. The present study found that antioxidant activity varied according to varieties and plant organs. In April, antioxidant activity was the highest in the leaves of Nonpareil variety and the lowest in Ferragnes (Figure 1). On the other hand, in stems, it was high in Nonpareil and Texas and low in Ferragnes in October (Figure 2).

Cosmulescu and Trandafir [27] investigated the seasonal variation of total phenols in the leaves of Juglans regia $\mathrm{L}$. They found that total phenols increased in June and July; decreased in August and increased in early September. They reported that there could be a correlation between phenolic content, season, genetic and ecological factors in walnut leaves. Sivaci and Sökmen [28] carried out a study on stem cuttings of Morus alba and Morus nigra and found that antioxidant activity and phenolic compounds showed seasonal variation. The highest antioxidant activity in stems was found in October.

In another study, variation of some phenolic compounds (phenylpropane chlorogenic acid and flavonoids such as rutin, hyperoside, epigenin-7-O-glucoside, kaempherole, quercitrin, quercetin and amentoflavone) in four Hypericum triquetrifolium populations in Central Black Sea Region were explored. Chemical variation was identified between the populations and plant sections and it was reported that these variations could be a result from different genetic, environmental and morphological factors [29]. In our study, total phenolic compounds varied according to season, variety and plant parts. The highest phenolic compound content in all varieties was observed in October in leaves; and in January in stems. The highest phenolic compound contents belonged to Nonpareil when compared to other varieties (Figures 3 and 4).

\section{Conclusions}

It was found that total antioxidant activity and phenolic compounds in Nonpareil, Texas and Ferragnes varieties exhibited variations according to season, plant organ (leaf and stem) and variety. This could be result from ecological, genetic and metabolic differences as indicated other studies $[27,29]$. Also, in the period during almond tree has no fruit, the leaves and stems could be made use of due to their antioxidant activity.

Further studies should be conducted to investigate the total antioxidant activity and phenolic profiles of almonds in next seasons.

\section{Methods}

\section{Plant materials}

Almond varieties (Nonpareil, Ferragnes and Texas) were collected from Lokman village of Adiyaman/Turkey (37 $42^{\prime} 15^{\prime \prime} \mathrm{N}, 38^{\circ} 19^{\prime} 11^{\prime \prime} \mathrm{E}, 1920$ feet) in 2011-2012. Leaves (April, July, October) and stems (April, July, October, January) of the almonds were analyzed. No analysis was performed in January because the plants had no leaves.

\section{Determination of antioxidant activity-DPPH}

Leaf and stem samples collected from almond varieties were dried and grinded. Grinded samples were taken to methanol $(\mathrm{MeOH})$ and extracted by shaking in water bath for 3 hours. Methanol extracts were then evaporated in evaporator under vacuum until they dried. Color of 2,2-diphenyl-1-picrylhydrazyl (DPPH) changes in the presence of antioxidant in the medium. Fifty microliters of various concentrations of almond variety extracts dissolved in methanol was added to in $5 \mathrm{~mL}$ of a $0.004 \%$ methanol solution of DPPH. The mixture was incubated at room temperature for 30 minutes and absorbance values were read at $517 \mathrm{~nm}$ [30]. Inhibition percent (I\%) of DPPH was calculated according to the following equation:

$$
\mathrm{I} \%=\left(\mathrm{A}_{\text {blank }}-\mathrm{A}_{\text {sample }} / \mathrm{A}_{\text {blank }}\right) \times 100
$$

where $A_{\text {blank }}$ is the absorbance of the control reaction (containing all reagents except the test compound) and $\mathrm{A}_{\text {sample }}$ is the absorbance of the test compound. Inhibition is concentration dependent, and extract concentration providing $50 \%$ inhibition $\left(\mathrm{IC}_{50}\right)$ is calculated from the graphplotted inhibition percentage against extract concentration. The assay was carried out in triplicate.

\section{Determination of total phenolic compounds}

The leaf and stem samples were homogenized in $2.5 \mathrm{ml}$ ethanol and shaken in water bath at $25^{\circ} \mathrm{C}$ for $24 \mathrm{~h}$. Homogenized samples were filtered. $1 \mathrm{ml}$ ethanol, $5 \mathrm{ml}$ distilled water and $1 \mathrm{ml}$ Folin-Ciocalteu reagent were added to $1 \mathrm{ml}$ of the filtered samples and shaken well. After 3 minutes, $3 \mathrm{ml}$ of $\mathrm{Na}_{2} \mathrm{CO}_{3}(2 \%$, w/v) was added and shaken in a dark medium at intervals for 2 hours. Absorbance values were read at $760 \mathrm{~nm}$ for phenolic 
compound amounts and amounts were determined according to standard gallic acid equivalence [31,32]. The assay was carried out in triplicate.

\section{Statistical analysis}

All analyses in this study were performed in three replicates. SPSS version 15.0 was used for statistical analyses. Duncan tests were used to determine the variations between the means. Differences at 5\% $(\mathrm{p}<0.05)$ level were considered as significant.

\section{Competing interests}

The authors declare that they have no competing interests.

\section{Authors' contributions}

AS carried out conception and design of the study, acquisition of data, /analysis and interpretation of data, drafting the manuscript and revising. SD carried out acquisition of data, analysis and interpretation of data, statistical analysis. Both authors read and approved the final manuscript.

\section{Acknowledgements}

This study was supported by Adıyaman University Scientific Research Projects Unit (SRP). I would like to thank Hüseyin Bereket from Lokman village, who is the grower of the almond varieties using in this study, and Dr. Riza Binzet who helped field studies.

\section{Author details}

'Department of Biology, Art and Science Faculty, Adiyaman University, Adiyaman, Turkey. ${ }^{2}$ Graduate School of Sciences, Adiyaman University, Adiyaman, Turkey.

Received: 24 August 2013 Accepted: 27 December 2013 Published: 1 April 2014

\section{References}

1. Ahmed M, Fayyaz U-H, Aslamt M, Aslam MA: Physiological attributes based resilience of wheat to climate change. Int J Agric Biol 2012, 14:407412.

2. Olesen JE, Trnka M, Kersebaum KC, Skjelvag AO, Seguin B, Peltonen-Sainio P, Rossi F, Kozyra J, Micale F: Impacts and adaptation of European crop production systems to climate change. European J Agron 2011, 34:96-112.

3. Wang X, Cal J, Jang D, Liu F, Daı T, Cao W: Pre-anthesis high- temperature acclimation alleviates damage to the flag leaf caused by post-anthesis heat stress in wheat. J Plant Physiol 2011, 168:585-593.

4. Agunbiade SO, Olanlokun JO: Evaluation of some nutritional characteristics of Indian almond (Prunus amygdalus) nut. Pakistan I Nutr 2006, 5:316-318.

5. Ahrens S, Venkatachalam M, Mistry AM, Lapsley K, Sahte SK: Almond (Prunus dulcis L.) protein quality. Plant Foods Hum Nutr 2005, 60:123-128.

6. Corderro V, Monterro A: Almond growing in Tras-os-Montes region (Portugal). Acta Hort 2001, 591:161-165.

7. Dokuzoguz M, Gulcan R: Researchs on breeding of almond genotypes (Prunus amygdalus L.) by the selection in Eagean Region and they adaptation. Turkey: Tübitak Toag; 1973:22.

8. Gulcan R: Physiological and morphological studies on selected types of almond. E.U. Bornova: Faculty of Agriculture Publications; 1976:72. No. 310.

9. Kuden A: Almond germplasm and production in Turkey and the future of almonds in the GAP area. Acta Hort 1997, 470:29-33.

10. Misirlı A, Gulcan R: Almond growing in Turkey. Nucis 2000, 9:3-6.

11. Zafar Shoaıb M, Muhammad F, Javed I, Akhtar M, Khalıq T, Aslam B, Waheed A, Yasmın R, Zafar H: White mulberry (Morus alba): a brief phytochemical and pharmacological evaluations account. Int J Agric Biol 2013, 15:612620 .

12. Exarchou V, Nenadıs N, Tsımıdou M, Gerothanasssıs IP, Troganıs A, Boskou D: Antioxidant activities and phenolic composition of extracts from Greek Oregano, Greek Sage, and Summer Savory. J Agr Food Chem 2002, 50:5294-5299.
13. Velıoglu YS, Mazza G, Gao L, Oomah BD: Antioxidant activity and total phenolics in selected fruits, vegetables, and grain products. $J$ Agr Food Chem 1998, 46:4113-4117.

14. Madhavi DL, Deshpande SS, Salunkhe DK: Food Antioxidants: Technological: Toxicological and Health Perspectives. Newyork: Markel Dekker; 1996:41-50.

15. Shahıdı F, Wanasundara PKJPD: Phenolic antioxidants. Critical Rev Food Sci and Nutr 1992, 32:67-103.

16. Naczk M, Shahıdı F: Extraction and analysis of phenolics in food. J Chromatography A 2004, 1054:95-111.

17. Taiz L, Zeiger E: Plant Physiology. 4th edition. Inc: Sinauer Associates; 2006:764.

18. Yang R, Tsao R: Optimization of a new mobile to know the complex and real polyphenolic composition: Towards a tool phenolic index using high performance liquid chromatography. J Chromatography A 2003, 1018:29-40.

19. Barreira JCM, Ferreıra ICFR, Olıverra MBPP, Pereira JA: Antioxidant activity and bioactive compounds of ten Portuguese regional and commercial almond cultivars. Food and Chem Toxicol 2008, 46:2230-2235.

20. Bollıng BW, Dolnikowskı G, Blumberg JB, Olıver Chen CY: Polyphenol content and antioxidant activity of California almonds depend on cultivar and harvest year. Food Chem 2010, 122:819-825.

21. Esfahlan AJ, Jamei R, Esfahlan RJ: The importance of almond (Prunus amygdalus L.) and its by-products. Food Chem 2010, 120:349-360.

22. Milbury PE, Chen CY, Dolnıkowskı GG, Blumberg JB: Determination of flavonoids and phenolics and their distribuition in almonds. J of Agr Food Chem 2006, 54:5027-5033.

23. Yıldırım AN, San B, Koyuncu F, Yıldırım F: Variability of phenolics, a tocopherol and amygdalin contents of selected almond (Prunus amygdalus Batsch.) genotypes. J Food Agr Environ 2010, 8:76-79.

24. Nunes LCC, Galindo AB, Lustosa SR, Brasileiro MT, Do Egito AA, Freitas RM, Randau KP, Rolim Neto PJ: Influence of seasonal variation on antioxidant and total phenol activity of red propolis extracts. Adv Studies Biol 2013, 5:119-133.

25. Ignacıo J, Plazaola G, Becerril JM: Seasonal changes in photosynthetic pigments and antioxidants in beech (Fagus sylvatica) in a Mediterranean climate: implications for tree decline diagnosis. Aust J Plant Physiol 2001, 28:225-232.

26. Esfahlan AJ, Jamei R: Properties of biological activity of ten wild almond (Prunus amygdalus L.) species. Turk J Biol 2012, 36:201-209.

27. Cosmulescu S, Trandafir I: Seasonal variation of total phenols in leaves of walnut (Juglans regia L.) J. Med Plants Res 2011, 5:4938-4942.

28. Sivaci A, Sokmen M: Seasonal changes in antioxidant activity, total phenolic and anthocyanin constituent of the stems of two Morus species (Morus alba L. and Morus nigra L.). Plant Growth Regul 2004, 44:251-256.

29. Çırak C, Radušıenè J, Janulıs V, Ivanauskas L, Camaş N, Ayan AK: Phenolic constituents of Hypericum triquetrifolium Turra (Guttiferae) growing in Turkey: variation among populations and plant parts. Turk J Biol 2011, 35:449-456.

30. Gulluce M, Sokmen M, Daferera D, Agar G, Ozkan H, Kartal N, Polıssıou M, Sokmen A, Sahın F: In vitro antibacterial, antifungal, and antioxidant activities of the essential oil and methanol extracts of herbal parts and callus cultures of Satureja hortensis L. J Agr Food Chem 2003, 51:39583965.

31. Chandler SF, Dodds JH: The effect of phosphate, nitrogen and sucrose on the production of phenolics and solasidine in callus cultures of Solanum lacinitum. Plant Cell Rep 1983, 2:205-208.

32. Slinkard K, Singleton VL: Total phenol analyses: automation and comparison with manual methods. Am J Enol Viticult 1977, 28:49-55.

doi:10.1186/0717-6287-47-9

Cite this article as: Sivaci and Duman: Evaluation of seasonal antioxidant activity and total phenolic compounds in stems and leaves of some almond (Prunus amygdalus L.) varieties. Biological Research 2014 47:9. 